\title{
Study the quality of school environment as new habitat for allergenc mites in Cairo, Egypt
}

\author{
Mohammad, K. yassin ${ }^{1}$; Zakia, E. Ashmawy ${ }^{2}$ and Aml, A. Hasanin ${ }^{2}$ \\ 1- Department of Zoology, Faculty of Science, AL- Azhar University \\ 2- Department of Zoology, Faculty of Science for girls, AL- Azhar University
}

\begin{abstract}
The present study was conducted on eight schools representing four different districts in Cairo Governorate from December 2006 till November 2007. The total annual number of school dust mites collected was relatively low (66 individuals). Shobera Al-khama schools embraced the highest population mite density (65.15\%) followed by Al- Abassia (16.16\%), Al-Salam city $(9.09 \%)$ and Nasr city recorded the lowest population density $(7.58 \%)$. The most abundant family collected was Pyroglyphidae representing $27.27 \%$ of the total number distributed between two different species of the Genus Dermatophagoides (D.pteronyssinus and D. farinae). This followed by families Cheyletidae and Dermanyssidae, each comprises $25.75 \%$ of the total with a single species for each; Cheyletus malccensis and Dermanyssus sp., respectively. Family Acaridae was represented by (21.21\% of the total) and came later in abundance. The average number $/ 5 \mathrm{gm}$. dust ranged between only one individual during April and July and 20 individuals during November, however completely absent during March and September. dermanyssids and acarids were present in seven months, cheyletids in six months and pyroglyphids in five months. All mite species were recorded with relatively higher rate during cold months reaching its maximum in January for Pyroglyphidae and Acaridae and during October and November for Cheyletidae and Dermanyssidae. The lower rate of these mites obtained during hot months. These results indicate that the lower the temperature, the higher population density of school dust mites.
\end{abstract}

Keywords: Allergenc, mites, Egypt

\section{INTRODUCTION}

Members of family Pyroglyphidae (Astigmata) are shed skin feeders and predominate inside houses. They are of considerable medical importance because they produce allergens, which cause bronchial asthma, perennial rhinitis and some respiratory disorders in sensitive patients (Maunsell et al., 1968 and Voorhorst et al., 1970). Many studies have been devoted to the active fauna of human habitation, especially those occurring in houses and other institutions dust. In Egypt El-Sherbiny, et al., 2010: study the prevalence of house dust mites in Al-Arish city, North Sinai Governorate. Khalifa et al. (1974) and Salem (1980) found that children suffering from asthmatic bronchitis comprised $60 \%$ of the patients. Those workers were able to prone immune-diagnostically that house was an active factor inducing asthmatic bronchitis among children patients. The nature and source of specific extrinsic allergens present in house dust extract were liable to much confusion. The workers in this field have emphasized that Dermatophagoides pteronyssinus and D. farinae lie at the top of house dust mites as main source of environment pollutants with house dust mite's allergens (Pauli et al., 1972; Arlian et al., 1982; Gamal-Eddin et al., 1989; 
Yassin, 1999 and Yassin et al., 1997). Later on, other mites belong to different families have been isolated from house dust and proved as being sources of allergens in different carried now different names according to the habitat of these mites, as house dust mite allergy, storage mite allergy and barn allergy. The intensity of infection is usually a reflection of the microenvironment provided for the mites by the life ways and habits of man, as well as the climate of the region in which they are found (Mitchell et al., 1969). The organic components originate from many sources such as: molds, bacteria, pollen, food particles, and human and animal dander. They represented the source of nourishment for a variety of mites and other arthropodvectors of diseases are quite abundant in this habitat (Richard et al., 2006). The prevalence of asthma, rhinitis, contact dermatitis and/or allergy individuals susceptible or sensitive to house dust mites has increased worldwide, especially among pre-school and school aged children (National Academy Press, 2000). Many causes have been proposed for this increase including changes in the standard of living, fever infections during early childhood, exposure to cigarette smoking and other irritants and outdoors and indoors allergens, damp housing and the presence of moulds in the home (Smedje et al., 1997). There is a sufficient evidence of a causal relationship between exposures to house dust mite allergen and the development of asthma in susceptible children, the feasibility and effectiveness of physical interventions to the house dust mite allergens in low-income, urban homes environments remain elusive (Patrick et al., 2001). The indoor air exposures are more strongly linked to the increase of asthma prevalence than either outdoor air exposures or violence. Specifically, dust mite and tobacco smoke exposure are identified as both risk factors for the development of asthma, as well as factors that may exacerbate existing asthma (Ruth, 2003). Nadchatram, (2005) found that house dust mites lived in human contact from time immemorial. Human dander or dead skin constitutes the major organic component of the house dust ecosystem. They feed on dander, dust mites and human association will continue to co-exist as part of our environment. Efficient house-keeping practice reduces infestation.

Because the children attended school for a major part of their time, the present study was conducted to study the quality of the school environment. This is the great of importance and may affect asthmatic symptoms as stated by (Smedje et al., 1997).

\section{MATERIAL AND METHODS}

Twenty four school dust samples (monthly) from eight school classrooms of the four different districts in Cairo governorate were selected for this study as new habitats for allergenic mites. These are Shobra Al- Khaima, Al-Abassia, Al- Salam city and Nasr city. Two schools from each district were chosen covering the whole district. These districts represent variable socioeconomic standards, age, cleanliness and using of electrical cleaners. Collection of dust samples were carried out once monthly for a year from December 2006 till November 2007 using electrical vacuum cleaner Usfesa (Mod.Mam-101/Mam-202-306VM). The first and second districts are crowded, with low socioeconomic standard and do not use any electrical cleaners in their schools, while the third and fourth are not crowded, with relatively high socioeconomic standard and use electrical cleaners. Samples in bags were kept separately and labeled with its information sheet including date of collection, temperature and relative humidity and all are enclosed in a plastic bag, tied and taken to the laboratory. The mite fauna in the samples (5 gm fine dust for each) were 
isolated and mounted on microscopic slides in Hoyer's medium for examination, identification and counting.

\section{RESULTS}

The present study revealed that the total annual number of school dust mites collected was 66 individuals, distributed between the four districts are Shobra AlKhaima (43 individual representing 65.15\%), Al-Abassia (12 individuals representing $18.18 \%$ ) Al-Salam city (6 individuals representing 9.09\%) and Nasr city (5 individuals representing $7.5 \%$ ). The analysis of variance of these data indicated that the four districts are very highly significant source of variation in mite number $(\mathrm{P}>0.01)$. This means that the number of mites collected from school dust depend greatly on the location of school and the stander of living in the district (Table 1 and Fig.1).

Table 1: Monthly variations of school dust-mites in the four districts in Cairo governorate, Egypt.

\begin{tabular}{|c|c|c|c|c|c|}
\hline \multirow{2}{*}{ Months } & \multicolumn{4}{|c|}{ Districts } & \multirow{2}{*}{ Totals } \\
\hline & Shobra Al Khama & Al Abassia & Al Salam City & Nasr City & \\
\hline$\overline{\text { December } 2006}$ & 2 & ---- & 1 & 3 & 6 \\
\hline January 2007 & 12 & 2 & ---- & ---- & 14 \\
\hline February & 2 & 2 & 1 & $\begin{array}{ll}--- \\
\end{array}$ & 5 \\
\hline March & $\begin{array}{ll}--- \\
\end{array}$ & $\begin{array}{ll}--- \\
\end{array}$ & ---- & 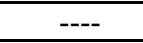 & $\begin{array}{ll}--- \\
\end{array}$ \\
\hline April & 1 & $\begin{array}{ll}--- \\
\end{array}$ & $\begin{array}{ll}--- \\
\end{array}$ & $\begin{array}{ll}--- \\
\end{array}$ & 1 \\
\hline May & 2 & $\begin{array}{ll}--- \\
\end{array}$ & ---- & ---- & 2 \\
\hline June & ---- & ---- & 1 & 1 & 2 \\
\hline July & 1 & --- & --- & ----- & 1 \\
\hline August & 2 & 2 & ---- & $\begin{array}{ll}--- \\
\end{array}$ & 4 \\
\hline September & --- & --- & --- & ---- & --- \\
\hline October & 3 & 4 & 3 & 1 & 11 \\
\hline November & 18 & 2 & ---- & $\begin{array}{ll}---- \\
\end{array}$ & 20 \\
\hline Totals & 43 & 12 & 6 & 5 & 66 \\
\hline Percentage \% & 65.15 & 18.18 & 9.09 & 7.58 & \\
\hline
\end{tabular}

Analysis of variance

\begin{tabular}{l|c|c|c|c|}
\hline Source of Variation & D.F. & SS & MS & F-value \\
\hline Month & 11 & 7.194 & 0.654 & 1.725 \\
\hline County & 3 & 5.232 & 1.744 & $4.601^{* *}$ \\
\hline Error & 33 & 12.509 & 0.379 & \\
\hline Total & 47 & 24.935 & & \\
\hline
\end{tabular}

D.F. $=$ Degree of freedom. $\mathrm{MS}=$ Mean square. $\mathrm{SS}=$ Sum squares. $* *=$ Significant at 0.01

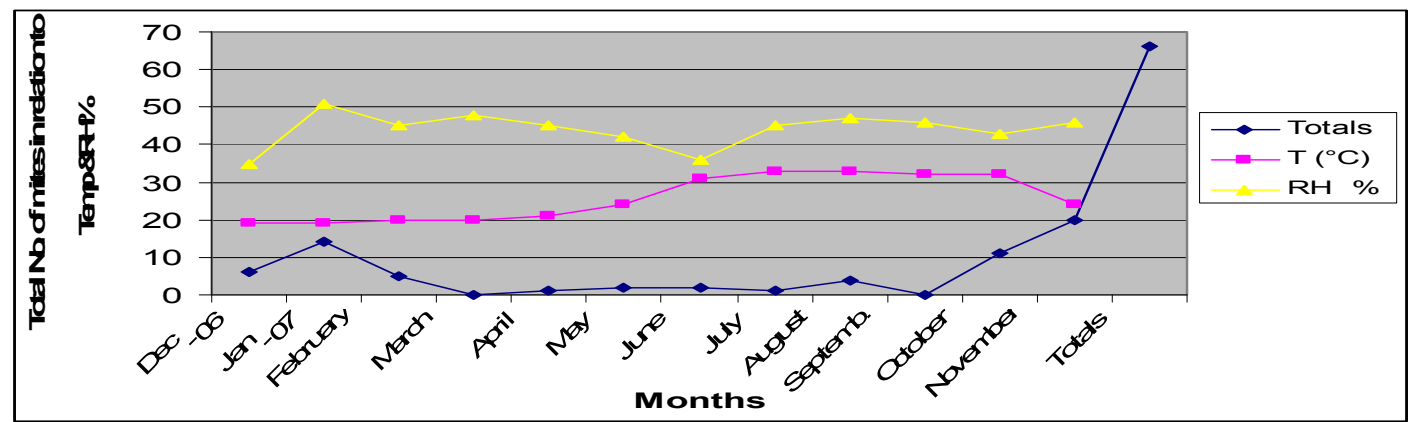

Fig. 1: Monthly total numbers of school dust-mites in relation to relative humidity (RH\%) and temperature $\left({ }^{\circ} \mathrm{C}\right)$ in Cairo governorate from December 2006 till November 2007.

Five different species of mites of different families were encountered during the present investigation. The most abundant family was Pyroglyphidae (18 
individuals representing $27.27 \%$ of the total number) distributed between two different species of the genus Dermatophagoides (10 of D. pteronyssinus and 8 of $D$. farinae).This followed by families Cheyletidae and Dermanyssidae, each comprises $26.75 \%$ of the total with 17 individuals of a single species for each, Cheyletus malaccensis and Dermanyssus sp., respectively. Family Acaridae was represented by 14 individuals (21.21\% of the total) and came later in abundance (Table 2 and Fig. 2).

The statistical analysis of the data indicated that the variation in number between different species was statistically non- significant and months were highly significant $(\mathrm{P}>0.01)$. This indicate that these mites are not permanent inhibitors of the school but they are occasional invaders comes to the schools by the bodies of the pupils.

Table 2: Monthly variations of school dust-mites in Cairo governorate from December 2006 till November 2007.

\begin{tabular}{|c|c|c|c|c|c|c|c|c|}
\hline \multirow[b]{2}{*}{ Months } & \multicolumn{2}{|c|}{ Pyroglyphidae } & \multirow[b]{2}{*}{ Cheyletidae. } & \multirow[b]{2}{*}{ Acaridae } & \multirow[b]{2}{*}{ Dermanyssidae. } & \multirow[t]{2}{*}{ Totals } & \multirow{2}{*}{$\begin{array}{l}\text { Ambiant } \\
: \text { C(Mean }\end{array}$} & \multirow{2}{*}{$\begin{array}{l}\text { humidity } \\
\text { R.H. \% }\end{array}$} \\
\hline & D.sp1 & Dsp2 & & & & & & \\
\hline December 2006 & 1 & 1 & 1 & 2 & 1 & 6 & 19 & 35 \\
\hline January 2007 & 4 & 1 & 4 & 4 & 1 & 14 & 19 & 51 \\
\hline February, & 1 & 1 & $\begin{array}{ll}-- \\
--\end{array}$ & 2 & 1 & 5 & 20 & 45 \\
\hline March & --- & --- & $-\cdots$ & --- & --- & --- & 20 & 48 \\
\hline April & --- & --- & --- & --- & 1 & 1 & 21 & 45 \\
\hline May & 2 & --- & --- & --- & --- & 2 & 24 & 42 \\
\hline June & --- & & 1 & 1 & --- & 2 & 31 & 36 \\
\hline July & --- & 1 & --- & --- & --- & 1 & 33 & 45 \\
\hline August & --- & --- & 2 & 1 & 1 & 4 & 33 & 47 \\
\hline September & --- & --- & --- & --- & --- & --- & 32 & 46 \\
\hline October & --- & --- & 7 & 2 & 2 & 11 & 32 & 43 \\
\hline November & --- & --- & 2 & 2 & 10 & 20 & & \\
\hline Totals & 10 & 8 & 17 & 14 & 17 & & & \\
\hline Percentage \% & \multicolumn{2}{|c|}{27.27} & 25.76 & 21.21 & 25.76 & & & \\
\hline
\end{tabular}

Analysis of variance

\begin{tabular}{|l|c|c|c|c|}
\hline \multicolumn{1}{|c|}{ Source of Variation } & D.F. & SS & MS & F-value \\
\hline Months & 11 & 6.955 & 0.632 & $3.002^{* *}$ \\
\hline Species & 4 & 1.198 & 0.299 & 1.422 \\
\hline Error & 44 & 9.267 & 0.211 & \\
\hline Total & 59 & 17.421 & & \\
\hline
\end{tabular}

D. $\mathrm{sp} 1=$ Dermatophagoides pteronyssinus $* *=$ Significant at 0.01

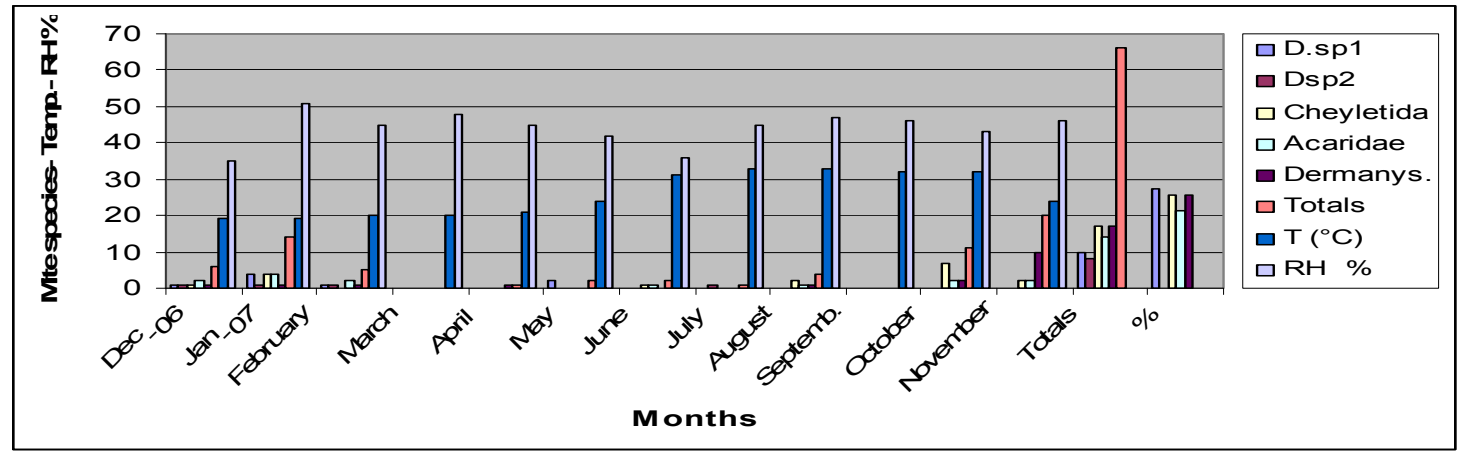

Fig. 2: Monthly variations of school dust-mites in Cairo governorate from December 2006 till November 2007.

From Tables ( 3 to 8 ) it was noticed that the incidence of the five species mites varied greatly between the four districts. The five species of families Pyroglyphidae, Dermanyssidae, Acaridae and Cheyletidae were all collected from Shobra ALkhaima representing the highest abundance $(12,13,10$, and 8 individuals, respectively). On the other hand, $D$. farinae is completely absent from school of Nasr 
city. The other species were represented by very few numbering at Al-Slam city and Nasr city (Tabs.3 \& Fig3).

Regarding the distribution of mites between the four seasons of the year at Shobra Al-Khaima district, autumn yields the highest number 23 individuals representing $53.49 \%$ of the total mite number (43 individuals) followed by winter $(32.56 \%)$ and then come spring and summer with the lowest mite density (3 individuals for each representing $6.97 \%$ of the total number) (Table 4 \&Fig.4).

Table 3: Seasonal variations of school dust mites / $5 \mathrm{gm}$ fine dust at four different districts in Cairo Governorate.

\begin{tabular}{|c|c|c|c|c|c|c|c|c|c|c|c|c|c|c|c|c|c|c|c|c|c|c|c|c|c|c|}
\hline \multirow[b]{2}{*}{ Species } & \multicolumn{5}{|c|}{ Autumn } & \multicolumn{5}{|c|}{ Winter } & \multicolumn{5}{|c|}{ Spring } & \multicolumn{5}{|c|}{ Summer } & \multicolumn{4}{|c|}{ Totals } & \multirow[b]{2}{*}{ 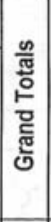 } & \multirow[b]{2}{*}{ 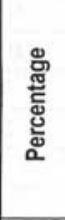 } \\
\hline & 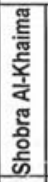 & 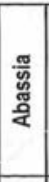 & 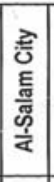 & $\begin{array}{l}\text { 청 } \\
\text { 总 } \\
\text { 己 }\end{array}$ & 푱 & 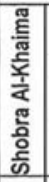 & 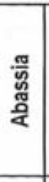 & 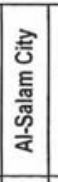 & 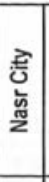 & 푱 & 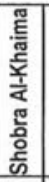 & 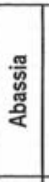 & 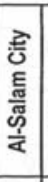 & 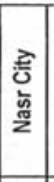 & 픙 & 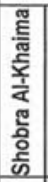 & 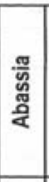 & 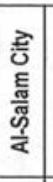 & 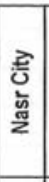 & 푱 & 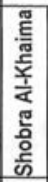 & 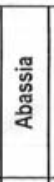 & 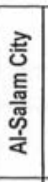 & 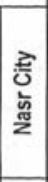 & & \\
\hline 1-D. pteronyssinus & 2 & - & - & 1 & 3 & 3 & - & 1 & - & 4 & - & - & - & - & - & 2 & 1 & - & - & 3 & 7 & 1 & 1 & 1 & 10 & 15.15 \\
\hline 2-D. farinae & 3 & 2 & 1 & - & 6 & 2 & - & - & - & 2 & - & - & -- & - & -- & - & - & -- & -- & - & 5 & 2 & 1 & - & 8 & 12.12 \\
\hline 3- T. putrescentiae & 8 & 2 & 1 & 1 & 12 & 1 & - & - & - & 1 & 1 & - & - & - & 1 & - & - & -- & -- & -- & 10 & 2 & 1 & 1 & 14 & 21.21 \\
\hline 4- C. malaccensis & 6 & 1 & 1 & 1 & 9 & 2 & 4 & - & - & 6 & - & - & 1 & 1 & 2 & - & -- & -- & - & - & 8 & 5 & 2 & 2 & 17 & 25.76 \\
\hline 5- Dermanyssus sp. & 4 & 1 & 1 & 1 & 7 & 6 & - & - & - & 6 & 2 & - & - & -- & 2 & 1 & 1 & -- & - & 2 & 13 & 2 & 1 & 1 & 17 & 25.76 \\
\hline Total & 23 & 6 & 4 & 4 & 37 & 14 & 4 & 1 & - & 19 & 3 & - & 1 & 1 & 5 & 3 & 2 & -- & - & 5 & 43 & 12 & 6 & 5 & 66 & \\
\hline
\end{tabular}

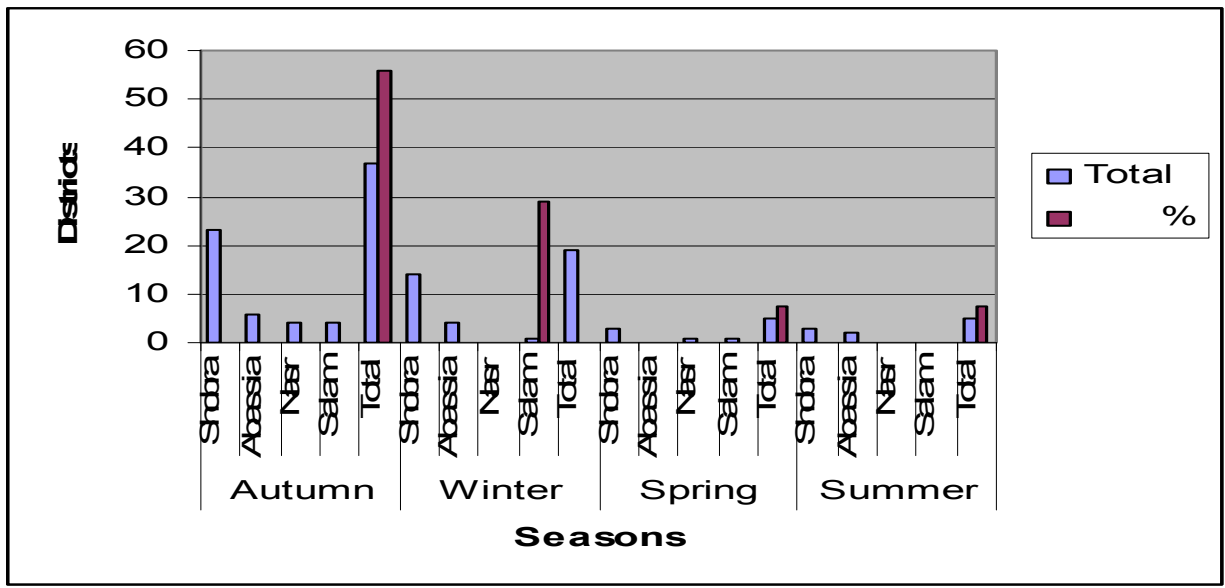

Fig. 3: Seasonal variations of school dust mites / $5 \mathrm{gm}$ fine dust at four different districts in Cairo Governorate.

The statistical analysis of the data of seasonal variation in mite fauna collected from schools from Shobra Al-Khaima indicates that species is not significant while season is highly significant source of variation in mite density at Shobra Al-Khaima, this indicates that the mites density is highly affected by season but species composition is not affected.

On conclusion, the school mite fauna collected during the course of the present work (Tables, 2 and 3) can be divided into the following two groups according to their population densities:

Group A: includes the highly prevalent mite species that occurs at relatively higher densities and these can be arranged descending according to their population as follows:

1- Species belonging to family Pyroglyphidae (Dermatophagoides pteronyssinus Trouessart, 1897 and Dermatophagoides farinae Hughes, 1961) 
and their total population together constitute $27.27 \%$ of the total mite population collected (Table 3 and Fig. 2).

2- Species belonging to family Cheyletidae (Cheyletus malaccensis Oudemans, 1903), its population represents $25.75 \%$ of the total population of school mites collected.

3- Species belonging to family Dermanyssidae (Dermanyssus sp. De Geer, 1834), its population density reached the same percentage mentioned above $25.75 \%$ of the total population of the mites collected.

Group B: includes mite species that occurs at relatively low population densities as compared with the first group and includes one species belonging to family Acaridae (Tyrophagus patrescentiae Shrank, 1781), its population density constitutes $21.21 \%$ of the total population of school dust mites collected.

Table 4: Seasonal variations of school dust-mites collected from four districts in Cano Governorate, Egypt (from December 2006 to November 2007).

\begin{tabular}{|l|c|c|c|c|c|c|}
\hline \multirow{3}{*}{ Seasons } & \multicolumn{3}{|c|}{ Districts } & \multirow{2}{*}{ Totals } & \multirow{2}{*}{$\%$} \\
\cline { 2 - 6 } & Shobra Al-Khaima & Al-Abassia & Al-Salam City & Nasr City & & \\
\hline Autumn & 23 & 6 & 4 & 4 & 37 & 56.0 \\
\hline Winter & 14 & 4 & 1 & --- & 19 & 28.8 \\
\hline Spring & 3 & 0 & 1 & 1 & 5 & 7.6 \\
\hline Summer & 3 & 2 & 0 & 0 & 5 & 7.6 \\
\hline Totals & 43 & 12 & 6 & 5 & 66 & \\
\hline$\%$ & 65.15 & 18.18 & 9.09 & 7.58 & & \\
\hline
\end{tabular}

Analysis of variance

\begin{tabular}{|l|c|c|c|c|}
\hline \multicolumn{1}{|c|}{ Source of Variation } & D.F. & SS & MS & F-value \\
\hline Season & 3 & 7.557 & 2.519 & $6.903^{* *}$ \\
\hline Districts & 3 & 9.157 & 3.052 & $8.365^{* *}$ \\
\hline Error & 9 & 3.284 & 0.365 & \\
\hline Total & 15 & 19.998 & & \\
\hline
\end{tabular}

D.F. $=$ Degree of freedom $\quad \mathrm{SS}=$ Sum squares $\mathrm{MS}=$ Mean square $* *=$ Significant at 0.01

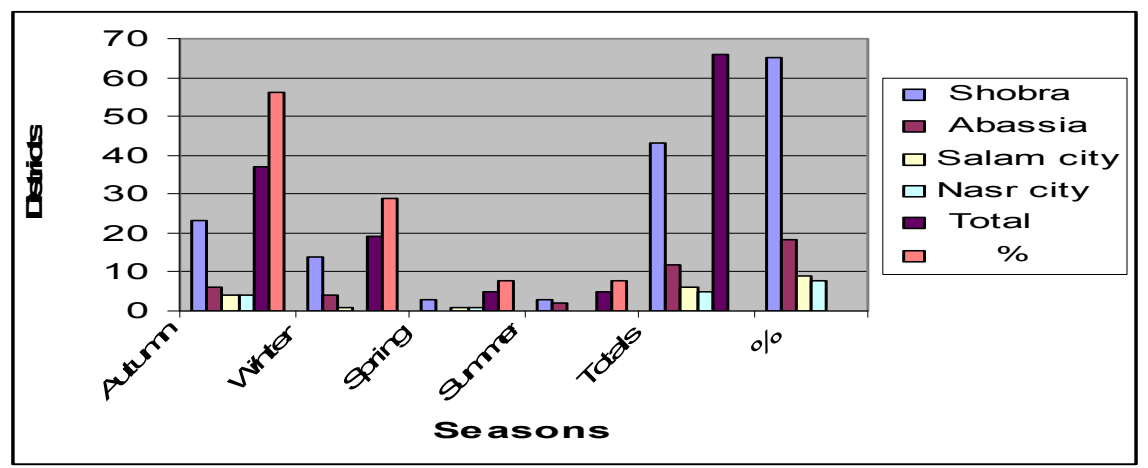

Fig. 4: Seasonal variations of school dust-mites collected from four districts in Cano

As shown in Table (5) the following species of school dust mites were encountered from Shobra Al-Khaima schools:

i- D. pteronyssinus and D. farinae (Family: Pyroglyphidae) representing $(27.90 \%)$ of the total number of mites collected from this county (43 individuals). $D$. pteronyssinus representing $(16.28 \%)$ and $D$. farinae $(11.62 \%)$.

ii- Tyrophagus putrescentiae (Acaridae) representing $(23.25 \%)$ from the total number of mites collected from Shobra Al-Khaima.

iii- Cheyletus malaccensis (Family: Cheyletidae) representing $18.60 \%$ of the total number of mites recorded from Shobra Al-Khaima. 
iv- Dermanyssus sp. (Family: Dermanyssidae) representing $30.24 \%$ of the total number of mites collected from Shobra Al-Khaima. Dermanyssidae ranks first in abundance being $30.26 \%$ followed by Pyroglyphidae $27.90 \%$ then Acaridae 23.25 $\%$ and Cheyletidae $18.60 \%$. The population densities of these mites were presented in Table (5) and illustrated in Figure (5).

Table 5: Seasonal variations of school dust-mites individuals/5 gm dust at Shobra Al Khaima district Cairo, Egypt.

\begin{tabular}{|c|c|c|c|c|c|c|}
\hline \multirow[b]{2}{*}{ Species } & \multicolumn{4}{|c|}{ Season } & \multirow[t]{2}{*}{ Totals } & \multirow[t]{2}{*}{$\%$} \\
\hline & Autumn & Winter & Spring & Summer & & \\
\hline D. pteron.. & 2 & 3 & ---- & 2 & $7 \quad(16.28)$ & \multirow[t]{2}{*}{27.90} \\
\hline D. farinae & 3 & 2 & $\begin{array}{ll}--- \\
---\end{array}$ & $\begin{array}{ll}--- \\
--\end{array}$ & $5 \quad(11.62)$ & \\
\hline Acaridae (Ty. Put.) & 8 & 1 & 1 & ---- & 10 & 32.26 \\
\hline Cheyl. Malac. & 6 & 2 & ------ & $-\cdots$ & 8 & 18.60 \\
\hline Dermany. Sp. & 4 & 6 & 2 & 1 & 13 & 30.23 \\
\hline Totals & 23 & 14 & 3 & 3 & 43 & \\
\hline$\%$ & 53.49 & 32.56 & 6.97 & 6.97 & & \\
\hline Seasonal average R.H. \% & 41.3 & 48 & 41 & 46 & & \\
\hline Seasonal average $\mathrm{T}\left({ }^{\circ} \mathrm{C}\right)$ & 25 & 19.6 & 25.3 & 32.6 & & \\
\hline
\end{tabular}

Analysis of variance

\begin{tabular}{|l|c|c|c|c|}
\hline Source of variation & D.F. & SS & MS & F-value \\
\hline Species & 4 & 0.932 & 0.233 & 1.130 \\
\hline Season & 3 & 5.489 & 1.830 & $8.873^{\text {** }}$ \\
\hline
\end{tabular}

D.F. $=$ Degree of freedom $\mathrm{SS}=$ Sum squares $\quad \mathrm{MS}=$ Mean square $* *=$ Significant at 0.01

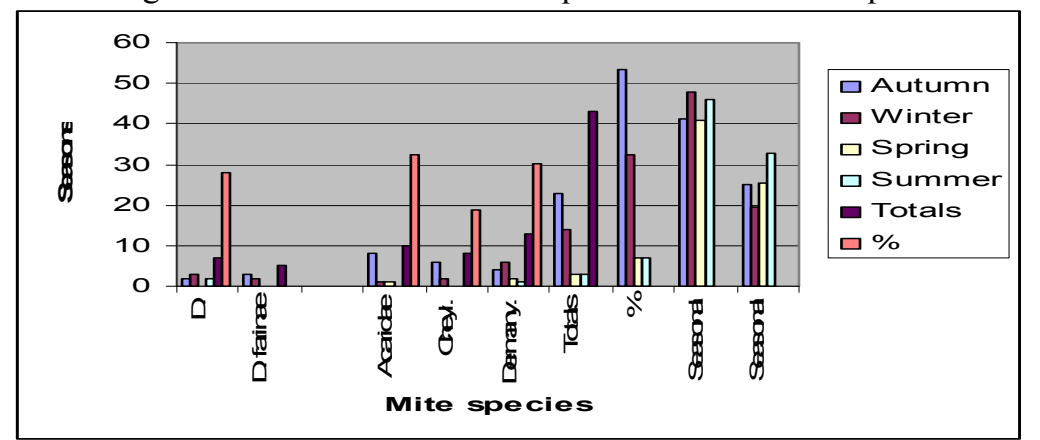

Fig. 5: Seasonal variations of school dust-mites individuals /5 gm dust at Shobra Al Khaima district Cairo, Egypt.

Regarding the distribution of mites between the four seasons of the year at Shobra Al-Khaima district, autumn yields the highest number 23 individuals representing $53.49 \%$ of the total mite number (43 individuals) followed by winter $(32.56 \%)$ and then come spring and summer with the lowest mite density (3 individuals for each representing $6.97 \%$ of the total number). The statistical analysis of the data of seasonal variation in mite fauna collected from schools from Shobra AlKhaima indicates that species is not significant while season is highly significant source of variation in mite density at Shobra Al-Khaima, this indicates that the mites density is highly affected by season but species composition is not affected.

The mite fauna of school dust collected from Al-Abassia district are shown in Table (6) and illustrated in Figure (8). It can be noticed from Table (6) that the mixed population of family Pyroglyphidae (D. pteronyssinus and D. farinae) represents $25 \%$ and comes second to family Cheyletidae that represents the highest density among other families (41.66 \% of the total number of mites encountered from this district). This followed by those of Acaridae and Dermanyssidae $16.66 \%$ for each.

The mite's number varied greatly from one season to other. autumn as in schools of Shobra Al-Khaima gave the highest number of individuals (50\%) 
followed by winter $(33.33 \%)$ and summer (16.67\%). Numbers of mites were collected during spring from Al-Abassia schools. Moreover, few species were collected during autumn; D. farinae, Tyrophagus putrescentiae, Cheyletiis malaccensis and Dermanyssus sp., one during winter, Cheyletus malaccensis and two species during summer; D. pteronyssinus and Dermanyssus sp. (Table 6 and Fig. 6).

Table: (6). Seasonal variations of school dust-mites individuals $/ 5 \mathrm{gm}$ dust at Abassia district Cairo, Egypt.

\begin{tabular}{|c|c|c|c|c|c|c|}
\hline \multirow{2}{*}{ Species } & \multicolumn{4}{|c|}{ Season } & \multirow[t]{2}{*}{ Totals } & \multirow[t]{2}{*}{$\%$} \\
\hline & Autumn & Winter & Spring & Summer & & \\
\hline D. pteron. & --- & $\begin{array}{c}--- \\
\end{array}$ & ---- & 1 & 1 & \multirow[t]{2}{*}{25.00} \\
\hline D. farinae & 2 & $\begin{array}{ll}--- \\
\end{array}$ & ---- & ---- & 2 & \\
\hline Acaridae (Ty. Put.) & 2 & ---- & $\begin{array}{c}--- \\
\end{array}$ & ---- & 2 & 16.66 \\
\hline Cheyl. Malac. & 1 & 4 & ---- & ---- & 5 & 41.66 \\
\hline Dermany.sp. & 1 & ---- & $\begin{array}{ll}--- \\
\end{array}$ & 1 & 2 & 16.66 \\
\hline Totals & 6 & 4 & $\begin{array}{ll}--- \\
\end{array}$ & 2 & 12 & \\
\hline Seasonal average R.H.\% & 41.3 & 48 & 41 & 46 & & \\
\hline Seasonal average $\mathrm{T}\left({ }^{\circ} \mathrm{C}\right)$ & 25 & 19.6 & 25.3 & 32.6 & & \\
\hline
\end{tabular}

Analysis of variance

\begin{tabular}{|l|c|c|c|c|}
\hline Source of Variation & D.F. & SS & MS & F-value \\
\hline Species & 4 & 0.281 & 0.070 & 0.391 \\
\hline Season & 3 & 0.795 & 0.265 & 1.475 \\
\hline Error & 12 & 2.155 & 0.180 & \\
\hline Total & 19 & 3.231 & & \\
\hline
\end{tabular}

D.F. $=$ Degree of freedom $\mathrm{SS}=$ Sum squares $\mathrm{MS}=$ Mean square $* *=$ Significant at 0.01

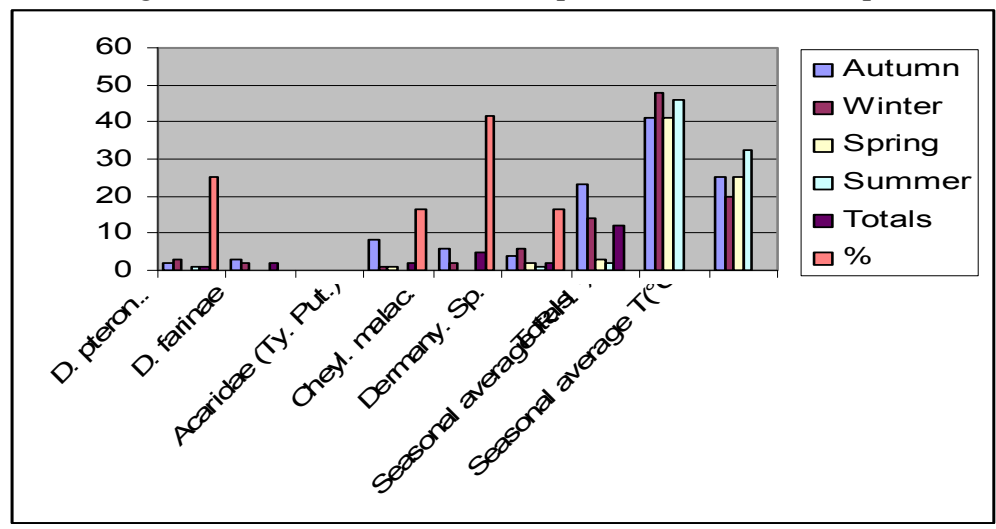

Fig. 6: Seasonal variations of school dust-mites individuals /5 gm dust at Abassia district Cairo, Egypt.

The statistical analysis of the data indicates that both species and seasons are not significant. This indicates that both mite density and species composition are not affected by seasons or species at this district and this confirm the previous finding that the mites are not inhibitors of those schools.

The mite fauna of school dust collected from schools at Al-Salam City (Table, 7 and Fig. 7) include the same four mite families recorded at both Shobra Al-Khaima and Al-Abassia districts ( Pyroglyphidae, Acaridae, Cheyletidae and Dermanyssidae) but with lower population densities; 2 individuals from each of Pyroglyphidae and Cheyletidae representing $33.33 \%$ for each, flowed by only one individual from each of Acaridae and Dermanyssidae representing $16.66 \%$ for each from the total.

The mites were completely absent from school dust at this district during summer months. autumn yields 4 individuals of four different species; $D$. farinae, Tyrophagusputrescentiae, Cheyletus sp. and Dermanyssus sp. On the other 
hand, only one specimen of $D$. pteronyssinus was collected during winter months and one Cheyletus sp. during spring (Table, 7 and Fig. 7).

Table 7: Seasonal variations of school dust-mites individuals /5 gm dust at Al Salam City, Cairo

\begin{tabular}{|c|c|c|c|c|c|c|}
\hline \multirow[b]{2}{*}{ Species } & \multicolumn{4}{|r|}{ Season } & \multirow[t]{2}{*}{ Totals } & \multirow[t]{2}{*}{$\%$} \\
\hline & Autumn & Winter & Spring & Summer & & \\
\hline D. pteron & ---- & 1 & ---- & ---- & 1 & \multirow[t]{2}{*}{33.33} \\
\hline$D$ farinae & 1 & --- & $\begin{array}{ll}--- \\
\end{array}$ & $\begin{array}{ll}--- \\
\end{array}$ & 1 & \\
\hline Acaridae (Ty. Put.) & 1 & ---- & ---- & ---- & 1 & 16.66 \\
\hline Cheyl. malac & 1 & $\begin{array}{ll}--- \\
--\end{array}$ & 1 & $\begin{array}{ll}--- \\
--\end{array}$ & 2 & 33.33 \\
\hline Dermany.sp. & 1 & ---- & --- & 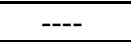 & 1 & 16.66 \\
\hline Totals & 4 & 1 & 1 & ---- & 6 & \\
\hline Seasonal average R.H. \% & 41.3 & 48 & 41 & 46 & & \\
\hline Seasonal average $\mathrm{T}\left({ }^{\circ} \mathrm{C}\right)$ & 25 & 19.6 & 25.3 & 32.6 & & \\
\hline
\end{tabular}

\section{Analysis of variance}

\begin{tabular}{|l|c|c|c|c|}
\hline Source of variation & D.F. & SS & MS & F-value \\
\hline Specie & 4 & 0.054 & 0.013 & 0.273 \\
\hline Season & 3 & 0.482 & 0.161 & $3.273^{*}$ \\
\hline Error & 12 & 0.589 & 0.049 & \\
\hline Total & 19 & 1.125 & & \\
\hline
\end{tabular}

D.F. $=$ Degree of freedom $S S=$ Sum squares $\quad$ MS $=$ Mean square $* *=$ Significant at 0.01

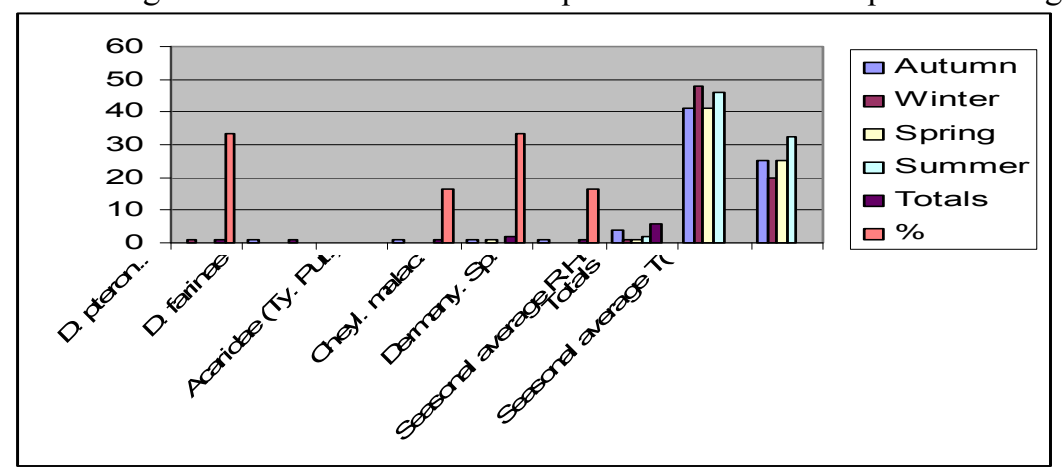

Fig. 7: Seasonal variations of school dust-mites individuals /5 gm dust at Al Salam City, Cairo

The lowest mite density was collected from schools in Nasr City. The mite fauna of school dust collected from Nasr City includes the same species mentioned before. Data concerning population density and seasonal variation are presented and illustrated in Table (8) and (Fig. 8).

Table 8: Seasonal variations of school dust-mites individuals $/ 5 \mathrm{gm}$ dust at Nasr City, Cairo

\begin{tabular}{|c|c|c|c|c|c|c|}
\hline \multirow[b]{2}{*}{ Species } & \multicolumn{4}{|c|}{ Season } & \multirow[t]{2}{*}{ Totals } & \multirow[t]{2}{*}{$\%$} \\
\hline & Autumn & Winter & Spring & Summer & & \\
\hline D. pteron & 1 & --- & $\begin{array}{ll}--- \\
\end{array}$ & $\begin{array}{ll}--- \\
--\end{array}$ & 1 & 20 \\
\hline D. farinae & --- & --- & $\begin{array}{ll}--- \\
\end{array}$ & ---- & --- & $-\cdots$ \\
\hline Acaridae (Ty. Put.) & 1 & --- & $\begin{array}{ll}--- \\
\end{array}$ & $\begin{array}{ll}--- \\
-1\end{array}$ & 1 & 20 \\
\hline Cheyl. Malac & 1 & --- & 1 & $\begin{array}{ll}--- \\
\end{array}$ & 2 & 40 \\
\hline Dermany.sp. & 1 & --- & $\begin{array}{ll}--- \\
\end{array}$ & $\begin{array}{ll}--- \\
\end{array}$ & 1 & 20 \\
\hline Totals & 4 & --- & 1 & $\begin{array}{ll}--- \\
-\end{array}$ & 5 & \\
\hline Seasonal average R.H. \% & 41.3 & 48 & 41 & 46 & & \\
\hline Seasonal average $\mathrm{T}\left({ }^{\circ} \mathrm{C}\right)$ & 25 & 19.6 & 25.3 & 32.6 & & \\
\hline
\end{tabular}

Analysis of variance

\begin{tabular}{|l|c|c|c|c|}
\hline Source of Variation & D.F. & SS & MS & F-value \\
\hline Species & 4 & 0.134 & 0.033 & 1.364 \\
\hline Season & 3 & 0.576 & 0.192 & $7.818^{* *}$ \\
\hline Error & 12 & 0.295 & 0.025 & \\
\hline Total & 19 & 1.005 & & \\
\hline
\end{tabular}

D.F. $=$ Degree of freedom $\mathrm{SS}=$ Sum squares $\mathrm{MS}=$ Mean square $* *=$ Significant at 0.01 


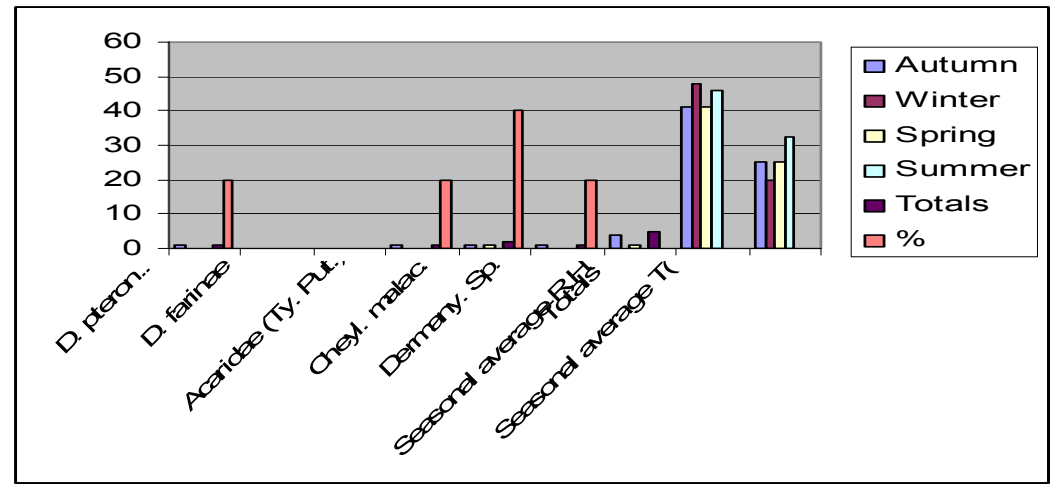

Fig. 8: variations of school dust-mites individuals /5 gm dust at Nasr City, Cairo

As shown in the table, the species of family Cheyletidae represents $40 \%$ of the number of mites collected from this county, followed by those of families Pyroglyphidae, Acaridae and Dermanyssidae $20 \%$ for each. However, D. farinae was not recorded in this county during the whole year round, and family Pyroglyphidae was represented only by one species, D. pteronyssinus. Autumn gave the largest number of mites 4 individuals one from each species except $D$. Farinae, which is not recorded followed by one individual mite of Cheyletus sp. in spring while, samples collected during winter and summer are empty and did not gave any mites.

The statistical analysis of data of seasonal variation of this district indicates that species is not significant while season is highly significant source of variation of mites this means that mite density is highly affected by seasons and is not affected by species variation.

\section{DISCUSSION}

The results obtained during the present work suggest that the habitat of schools infestation by dust mites in Cairo governorate is more or less similar to those recorded by other workers in different geographical zones. The number of species distinguished from schools dust, at four different districts (Shobra Al-Khaima, Al-Abassia, AlSalam City and Nasr City), are five species. These in order of abundance are Dermatophagoides pteronyssinus and D. farinae (family Pyroglyphidae), Cheyletus malaccensis (family Cheyletidae), Dermanyssus sp. (family Dermanyssidae) and Tyrophagus putrescentiae (family Acaridae).

However, it seems that Gamal Eddin et al. (1982) were the first author's initiating lie recent interest of house dust mites in Egypt. In their first paper, they recorded five of house dust mites from Nile Delta (Tanta Town). These are D. farinae, D. pteronyssinus, T. putrescentiae, Cheyletus malaccensis, Blomia kulagini and Acheles gracilis which is considered as new record for house dust mite fauna. Yassin (1990) recorded eight species of house dust mites from Cairo houses. These may be considered as reference of medically important house dust mites in this locality.

Only, few works were conducted in order to investigate mites in schools; Oshima (1964) and Nakada and Yoshikawa (1976) in Japan; Lang and Mulla (1978) in USA; and Abou Senna et al. (1996c) in Jeddah City, Saudi Arabia. All these works agreed with the present work in that the infestation of schools by mites is carried out by mechanical transmission. People and small mammals are probably the most important carriers of these mites from one locality to other. This is in complete agreement with Bronswijk (1974), who stated that house dust mites did not become established in new 
places until they become inhabited. On the other hand, Hewitt et al. (1973) have been found that mites are common on human clothing.

The low mite numbers found in school classrooms dust as compared by houses may be due to that schools classrooms are cleaned daily after school day. This is in agreement with Abou Senna et al. (1996c) who stated that this hygienic practice would probably remove mites as well as reduce human skin scales and other food detritus they feed on. Also, these results coincides with the observation of Lang and Mulla, (1978) working on Dermatophagoides spp. collected from Orange County elementary schools, California. On the other hand, the high mite counts in house dust collected from houses in Shobra Al-Khaima and Al-Abassia may due to the constant occupation of these houses by man which can add the required food (by his shed skin scales) and moisture to the physical habitat supporting mite population of dust.. These observations coincide with Arlian (1978) and Lang and Mulla (1978) who stated that mite counts are usually higher in articles of furniture that are used most frequently and are rare or absent in those articles not in use.

In the present work, two pyroglyphid mites are the most abundant ( $D$. pteronyssimts and $D$. farinae) representing $27.27 \%$ of the total number, followed by Cheyletus malaccensis and Dermanyssus sp. each comprises $25.75 \%$ of the total, then come Tyrophagus putrescentiae which represented $21.21 \%$ of the total. These results coincide with other investigations that dealt with the occurrence of mites in schools and institutions other than houses; Oshima (1964) found Dermatophagoides spp. to be dominant on floors of elementary and high schools in Japan; Nakada and Yoshikawa (1976) recorded only 3 Dermatophagoides spp. from seats and floors of 12 Tokyo Theaters, while Lang et al. (1978) found that 6 out of 9 elementary schools samples yielded mites of which $62 \%$ of specimens were D. pteronyssinus and the remaining being $D$. farinae. Abou Senna et al. (1996 c) in study of the abundance of mites in institutions other than houses in Jeddah City, Saudi Arabia, including six factories, five hotels, seven mosques and five elementary schools found mites in all samples, $D$. farinae and $D$. pteronyssinus were the most abundant. Factories dust gave the highest number of mites followed by hotels, mosques and schools come later with the lowest mites count.

The population density of mites was relatively higher in dust collected from schools of both Shobra Al-Khaima and Al-Abassia as compared by the other two districts (Al-Salam City and Nasr City) which gave a relatively lower numbers of mites. This may be attributed to the differences in the socioeconomic level between these districts, which are reflected on the cleaning level. This agreed with Smedje et al. (1997) who stated that the quality of the environment is of importance and may affect asthmatic symptoms. Also, these coincided with Charlet et al. (1977) who stated that accumulation of food deposits on which mites develop and reproduce leading to build up of mite population.

Concerning the seasonal variation in mite numbers, the data indicate that, the highest population was recorded during winter and autumn, while the lowest populations were recorded during summer. Correlating these results with the recorded temperatures and relative humidities, it is observed that mite populations were high when temperature was $25^{\circ} \mathrm{C}$ or below and the relative humidity was $45 \%$ or more. This finding is in complete agreement with Gamal Eddin et al. (1982) who stated that the $25^{\circ} \mathrm{C}$ may considered as the most favorable temperature (at $75 \%$ R.H.) for reproduction and breeding of both $D$. farinae and D. pteronyssinus. Also, Bronswijk and Sinha (1971) reported that under optimum or near optimum conditions the life cycle from egg to egg requires about a month for both $D$. farinae and $D$. 
pteronyssinus. Other workers reported the same findings (Dobson, 1972; Furmizo, 1973; Gamal Eddin et al., 1982 and Abou Senna et al., 1996 a \& b).

The scarce number of mites in school dust collected during the course of present work in some months clearly indicate that these schools are not a suitable site for living, reproduction and building up of mite populations and mites are not a permanent inhibitors of schools but it come as occasional invaders on the bodies and cloths of pupils from their houses. However, Gamal Eddin et al. (1982) discussed the factors affecting on the attraction of mites towards beds reaching to conclusion that mite reaction towards human being microhabitat may not be absolutely a response to only one factor and they believed that the reaction of mite to bed is a primarily an odoriferous response. Namely, the dominant factor, which affects the behavior of the mites, may be smell stimulus of the human sweat gland secretion and sebaceous gland secretion which permanently contaminate the surface of mattresses, lines, blankets and pillows. They were inclined to believe that the predilection and more congregation of pyroglyphid mites in bed rooms seem to be likely a main chemotatic response, depending on the degree of contamination which is greatly affected by the frequency of bathing, then comes the food, temperature and relative humidity, as regulating factors for distribution of mites inside houses and their Perpetuation of life and by breeding. This agrees completely with the present work since schools classrooms with its wooden desks and naked floors are not represent suitable ecological niches for attraction, or building up a high population of mites. And this confirms the present author view that schools are not a permanent habitat for these mites and the mites are occasional invaders.

As a final conclusion, the low numbers of mites collected from schools in Cairo City would probably thus plays an insignificant role in contributing to allergic disorders present in these schools. So the present author recommended that schools must by repeatedly vacuumed with a powerful electric sweeper every day after the school day in order to keep the mite density at the lowest value and minimize the chance of building up high population and this in turn reduce the probability of asthma attack to pupils in these schools.

\section{RECOMMENDATIONS}

According to the results obtained during the present work, the author can recommend that measures to prevent asthma in school children should include minimizing the amount of fittings and fixtures which attract and retain dust and school must be maintained dry by vacuum sweeper daily after the school day in addition to the personal factor. All the above mentioned measures constitute the quality of school environment which is importance and may affect asthmatic symptoms.

\section{REFFERENCES}

Abu Senna, F. M.;Gamal Eddin, F. M.; Kawashti, I.S. and Issa, W. A. (1996a): House dust mites in Jeddah City, Saudi Arabia, A-Fauna composition. Al- Azhar Bull. Sci. 7 (1).

Abu Senna, F. M.;Gamal Eddin, F. M.; Kawashti, I.S. and Issa, W. A. (1996b): House dust mites in Jeddah City, Saudi Arabia,B-Population density of Dermatophagoides spp. in relation to some ecological aspects. Al- Azhar Bull. Sci.7 (1):897-912.

Abu Senna, F. M.;Gamal Eddin, F. M.; Kawashti, I.S. and Issa, W. A. (1996c): Abundance of dust mites in institutions other than houses in Jeddah City, Saudi Arabia. C- Al- Azhar Bull. Sci.7 (1):791-798. 
Arlian,L. G.; Brandt, R. L. and Bernstien, I. L. (1978): Occurrence of house dust mites, Dermatophagoides spp. (Acari, Pyroglyphidae)during the heating season. J. Med.Ent.15 (1):35-42.

Arlian,L. G.; Bernstien, I. L. and Gallagher, J.S. (1982): The prevalence of house dust mites, Dermatophagoides spp., and associated environmental conditions in homes in Ohio. J. Allergy Clin., I mmunol., 69: 532-537.

Bronswijk,J. E.; Van, M. H. and Sinha, R. N. (1971): Pyroglyphidae mites (Acari) and house dust allergy. Allergy. 47:31-52.

Bronswijk,J. E. (1974): Colonization and its prevention on house floors and in mattresses with Dermatophagoides pteronyssinus (Acari: Sarcoptiformes) in a center for asthmatic children. Ent.Exp. Appl. 17:199-203.

Charlet, L. D.; Mulla, M. S. and Sanchez-Medina, M. (1977): Domestic Acarina of Colombia: Occurrence and abundance of Acari in house dust. Acarologia. 19(2): 112-119.

Dobson, R. M. and Sesay, H. R. (1972): Studies on the mite fauna of house dust in Scotland with Special reference to that bedding. Acarologia. 14:384-392.

El-Sherbiny, G.T., El-Sherbini, E.T., Saled, N.M., Haridy, F.M., Morsy, A. T. (2010): A study on the prevalence of house dust mites in Al-Arish city, North Sinai Governorate, Egypt. J. Egypt. Soc. Parasitol. 40, 1:57-70.

Furmizo, R.T. (1973): The biology and ecology of the house dust mite D. farinae Hughes, 1961 (Acarina: Pyroglyphidae) Ph. D. dissertation. University of California Riverside. pp 143.

GamalEddin,F. M.; Tayel, S. E., Abou Senna, F. M. and Shehata, K. (1982): Present status and ecology of house dust mites in Egypt as approches to environmental control of mites and preparation of specific diagnostic antigen before resort to any desensitizing vaccine. J. Egypt. Soc. Parasitol. 12:253-281.

GamalEddin,F. M.; Hammad, A. M. and Shokry, M. G. M. (1989):house dust mite in middle Egypt. J. Egypt. Soc. Allergy. Vol. 1.

Hewitt, M. G.; Barrow, I.; Miller, D. C.; Turk, S. (1973): Mites in the personal environmental and their role in skin disorders. Brit. J. Dermatol. 39: 404-409.

Khalifa,S. G. ; Shukrey, S. A. and El-Hefny, A. (1974): The role of eosinophils in extrinsic allergic bronchial asthma. M. Sc. Thesis (Pediatrics).Cairo University.

Lang, J. D. and Mulla, M. S. (1978): Seasonal dynamics of house dust mites, Dermatophagoides spp in rooms in Southern California. Env. Ent. 7: 281-286.

Mitchell, W. F. ; Wharton, G. W. ; Larso,d. g. AND modie, R. (1969): House dust mites and insects. Ann. Allergy. 27: 93-99.

Maunsell, K.; Wraith, D. G. and Cunington, A. M. (1968): Mites and house dust allergy in bronchial asthma. Lancet. 1; 1267-1270.

National Academy Press (2000): Clearing the Air: Asthma and Indoor Air Exposures: Constitution Avenue, N.W. Washington, D.C. 20418.

Nadchatram, M. 2005: House dust mites, our intimate associates (Intitute for Medical Research), Kuala Lumpur, Malaysia. Trop. Bio-med. 22(1):23-37.

Nakada, T. and Yoshikawa, S. (1976): Dermatophagoides spp. from seats and floors of Tokyo Theaters. Ann. Rep. Tokyo. Merto..Res. Lap.P.H.27: 264-269.

Oshima, S. (1964): Observations of floor mites collected in Yokohama. 1. on the mites found in several schools in summer. Jap. J. Sanit. Zool. 15: 232-244.

Paul, T. C. and Sinha, R. N. (1972): Low temperature survival of D. farinae. Ent. 1: 547-549.

Patrick, J. V.; Sandra, P.R. and James, S. (2001): Effects of physical interventions on house dust mite allergen levels in carpet, bed and upholstery dust in low-income, urban homes. Environ. Hlth. Perspect. 109 (8):815-9.

Richard, S., Stephen T.H., Thomas, Platts-Mills, A.E., Jeremy J. C. 2006: Exposure to House-Dust Mites Allergen (Der. P I) and the development of asthma in childhood. Thorax 55(5):24-431.

Ruth, A.E. 2003: How environmental exposures influence the development and exacerbation of asthma? Pediatrics 112(1):1-9.

Smedje, G.; Norbacr, D. and Edling, C. (1997): Asthma among secondary schoolchildren in relation to the school environment. Clin. Exper. Aller. 27 (11): 1270-8.

Salem, E. E. (1980): Skin testing in allergy, evaluation, limitations and experience of 72 cases of asthma. Egypt. J. Chest. disease and Tuberculosis. 3:2-97.

Voorhorst, R. (1970): Specific causes of bronchial asthma mites and house dust. Folia Allergol.ROOM.17: 394-395. 
Yassin, M. K. (1990): Taxonomical survey and some biological studies on house dust mites in Cairo Governorate with special emphasis on their role in respiratory disorders. Ph.D. Thesis Fac. Sci. Al-Azhar Uni. 200 pp.

Yassin, M. K. and Rifaat, M. M. A. (1997): Distribution and abundance of house dust mites, Dermatophagoides spp. in different ecological localities in Esna City, Kena Governorate, Egypt. J. Egypt. Soc. Parasitol. 27(2): 431-437.

\section{ARABIC SUMMARY}

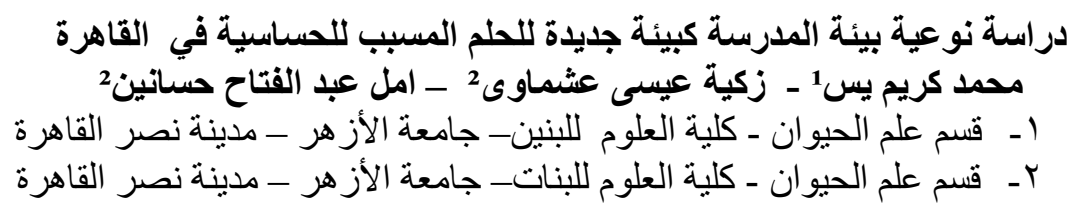

اهتم هذا البحث بدر اسة نوعية بيئة المدارس ومدى احتو ائها على الحلم المسبب للحساسية في غبار المدارس وكثافته العددية ، وتوزيعه في

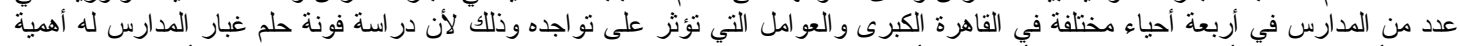

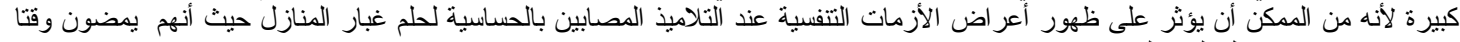

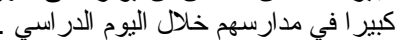

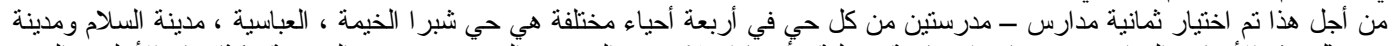

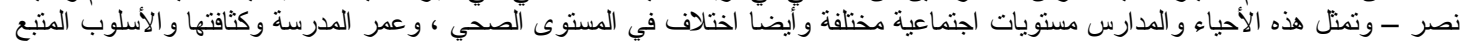

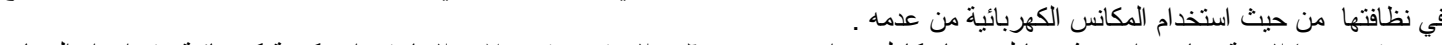

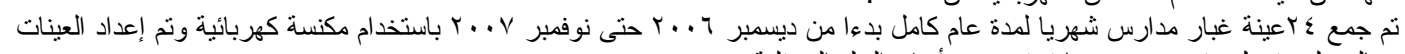

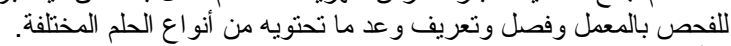
و أسفرت النتائج على ما ليلي:

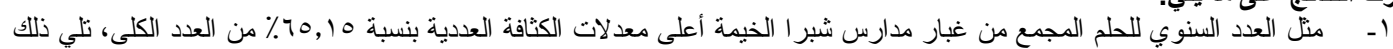

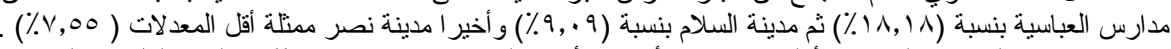

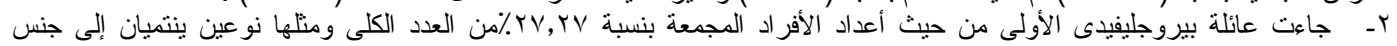

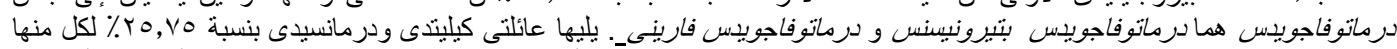

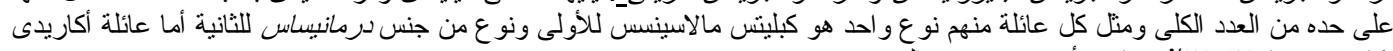

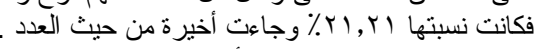

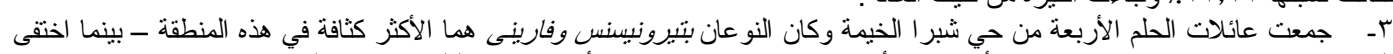

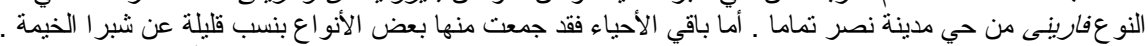

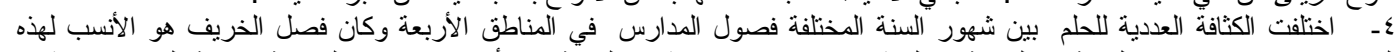

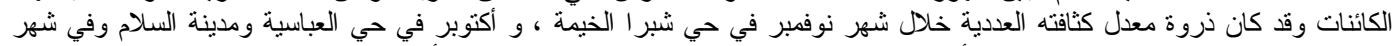

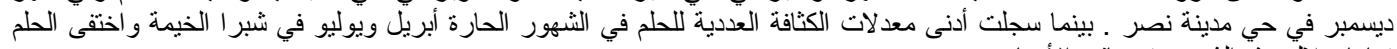

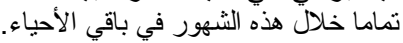

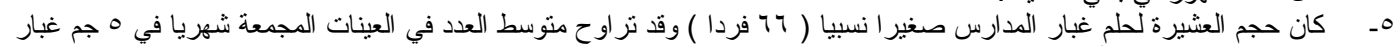

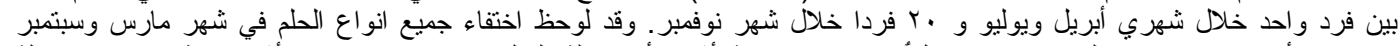

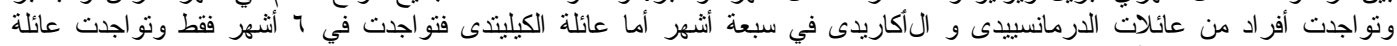

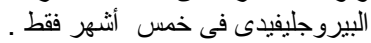

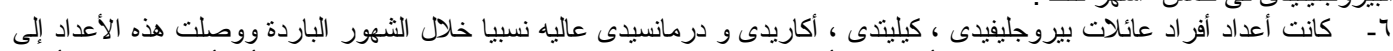

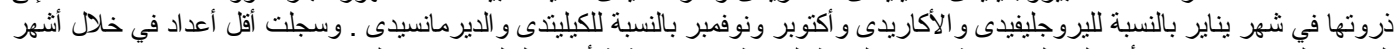

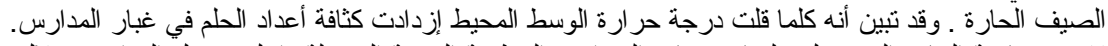

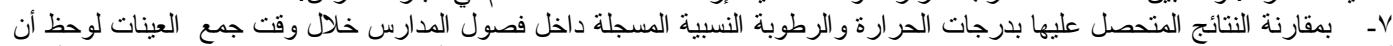

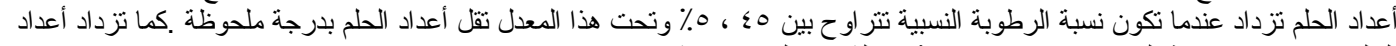

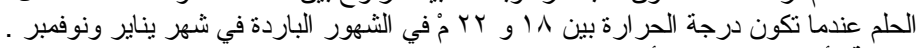

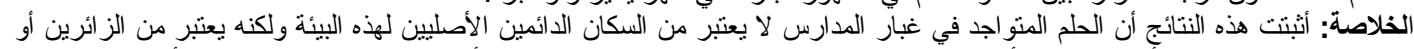

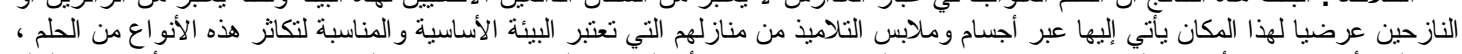

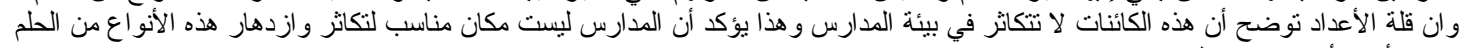

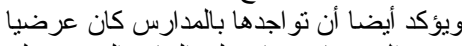

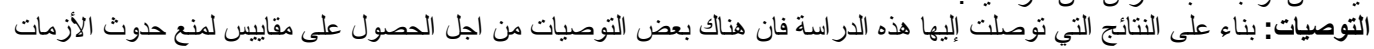

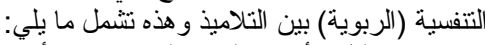

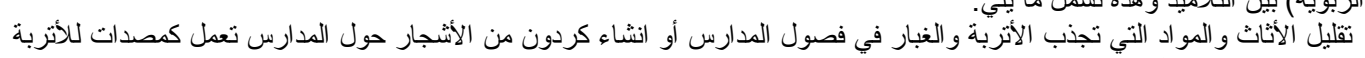

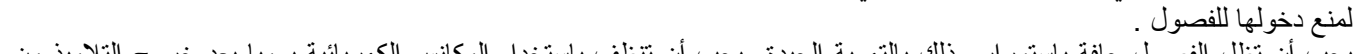
المدرسب أن تظل الفصول جافة باستمر ار وذلك بالتهوية الجيدة ويجب أن تتظف باستخدام المكانس الكهربائية يوميا بعد خروج التلاميذ من

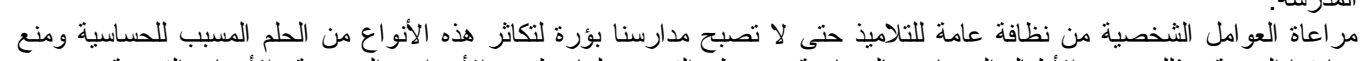

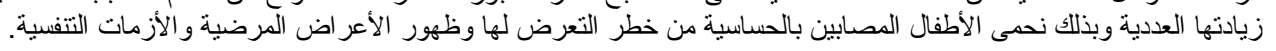

